\title{
The detection of Melissococcus pluton in honey bees (Apis mellifera) and their products using a hemi-nested PCR
}

\author{
Ben Alexander McKeE ${ }^{\mathrm{a}}$, Steven Philip DJORDJEVIC ${ }^{\mathrm{b}}$, Russell David GOODMAN ${ }^{\mathrm{c}}$, \\ Michael Alan HORNITZKY ${ }^{\mathrm{d} *}$ \\ a The University of Melbourne, Institute of Land and Food Resources, Parkville, Victoria, Australia, 3052 \\ b New South Wales Agriculture, Elizabeth Macarthur Agricultural Institute, Camden, New South Wales, \\ Australia, 2570 \\ ${ }^{c}$ Department of Natural Resources and Environment, Institute for Horticultural Development, Victoria, \\ Australia, 3176 \\ d NSW Agriculture, Elizabeth Macarthur Agricultural Institute, PMB 8, Camden, New South Wales, \\ Australia, 2570
}

(Received 24 August 2001; revised 5 February 2002; accepted 6 May 2002)

\begin{abstract}
A hemi-nested polymerase chain reaction (PCR) was further developed for the detection of Melissococcus pluton in adult bees and honey bee products. A chloroform:isoamyl alcohol DNA extraction method was used to provide template from 154 samples of adult bee tissues, honey, pollen, whole larvae and comb cells. All 36 honey bee samples tested from a diseased colony were shown to contain M. pluton and sub-clinical infections were detected in adult bee tissues, larvae and honey $(49 / 98 ; 50.0 \%)$ collected from all 9 healthy colonies from areas where EFB was endemic. All 20 adult bee tissue samples from a healthy colony from Western Australia where EFB has never been reported were negative. Of 80 bulk honey samples from six Australian states, 55 of 80 (68.8\%) samples were shown to contain M. pluton whereas culture techniques detected M. pluton in 22 of $80(27.5 \%)$ of these samples. M. pluton was detected in honey from all Australian states except Western Australia.
\end{abstract}

polymerase chain reaction / Melissococcus pluton / european foulbrood / honey bees / Australia

\section{INTRODUCTION}

European foulbrood (EFB) is a disease of honey bee larvae (Apis mellifera L.) caused by the bacterium Melissococcus pluton. It is widespread in most honey producing countries of the world; however, it has not been reported to occur in New Zealand or Western Australia (Hornitzky and Wilson, 1989). In Australia, it can be a serious disease that commonly occurs in spring when the broodnest is expanding (Graham, 1992).

Several methods have been used to detect M. pluton. These include microscopic examination of carbol fuchsin stained smears of dis- eased larvae (Hornitzky and Wilson, 1989), culture of bacteria from infected larvae or honey (Hornitzky and Smith, 1998), scanning electron microscopy (Alippi, 1991) and enzyme-linked immunosorbent assays (Pinnock and Featherstone, 1984). Although the isolation of $M$. pluton is not usually required for the diagnosis of EFB, specific and sensitive detection methods are required to ensure its absence from bee products for export purposes and for epidemiological studies.

Recently, two polymerase chain reaction (PCR) protocols were developed for the detection of M. pluton in honey bee larvae and pure cultures of the organism (Govan et al., 1998;

* Correspondence and reprints
E-mail: michael.hornitzky@agric.nsw.gov.au 
Djordjevic et al., 1998a). Govan et al. (1998) tested three bacterial species (Escherichia coli, Paenibacillus alvei and Staphylococcus aureus) to determine the specificity of their assay but did not determine the sensitivity of the assay. Djordjevic et al. (1998a) described a hemi-nested PCR for which the amplification of the first generation product was shown to be specific for $M$. pluton when tested against 27 bacterial species which were closely phylogenetically related to $M$. pluton or commonly cultured from honey bee hives. The first generation PCR was capable of detecting between 1-10 M. pluton organisms $/ \mathrm{ml}$ in serial titrations of an in vitro culture of $M$. pluton, a level of detection considerably more sensitive than direct culture. However, the sensitivity and specificity of the hemi-nested reaction was not determined and neither of these two studies reported the use of PCR for the detection of $M$. pluton in adult bees or bee products.

Attempts by Djordjevic et al. (1998a) to use this assay for the detection of $M$. pluton in honey and adult bees were unsuccessful (Djordjevic, unpublished results). More sensitive and robust methods using PCR for the detection of $M$. pluton in bees and bee products are important to better understand the ecology of M. pluton and for the certification of bee products free from $M$. pluton for export purposes. Culture procedures, serological procedures, scanning electron microscopy and the preparation of smears of such material are time consuming and often ineffective or insensitive for such purposes. The aim of this study was to further develop the hemi-nested PCR (Djordjevic et al., 1998a) for the sensitive detection of M. pluton in honey, pollen, whole larvae and adult bee tissues, and also to determine the prevalence of $M$. pluton in Australian bulk honey samples using PCR compared to conventional culture techniques.

\section{MATERIALS AND METHODS}

\subsection{Samples}

Fifteen, 4-5 day old larvae showing clinical signs of EFB and $25 \mathrm{ml}$ of broodnest honey were collected from the same colony to compare DNA extraction protocols for larvae and honey. For epidemiological studies 134 adult bee, broodnest honey, broodnest pollen, larvae and brood comb wash samples were collected from 10 colonies in areas where EFB was endemic and 20 adult bees were collected from one colony from Western Australia. Adult bees were collected using sterile forceps and dissected (Dade, 1962). Broodnest honey and pollen were collected from comb cells using a sterile spatula. Brood comb cell washes were obtained by soaking a sterile swab in sterilised distilled water (SDW) and rotating it in a single comb cell containing a freshly laid egg, before agitating the swab in $1 \mathrm{ml}$ of SDW for 30 seconds.

Eighty honey samples were collected from bulk honey drums from commercial packing plants located in different Australian States. These consisted of 27 samples from Victoria, 24 from New South Wales, 7 from Queensland, 11 from South Australia, 7 from Tasmania and 4 samples from Western Australia. Negative control samples of adult bees and honey were obtained from Western Australia where EFB has not been reported. Western Australian bulk honey $(25 \mathrm{~mL})$ was used as a negative control and a positive control was prepared inoculating a duplicate honey sample with approximately $2.5 \times 10^{4}$ cultured $M$. pluton organisms (Hornitzky and Smith, 1998).

\subsection{Diagnosis of EFB and culture of M. pluton from bulk honey samples}

EFB was confirmed in honey bee colonies by the microscopic examination (mag. 1000X) of diseased brood smears stained with carbol fuchsin (Hornitzky and Wilson, 1989). Bulk honey samples were cultured as described by Hornitzky \& Smith (1998) except that the culture medium contained $7 \%$ citrated sheep blood.

\subsection{DNA extraction protocols}

\subsubsection{Methods to extract DNA from honey}

For comparative DNA extraction studies broodnest honey which had been heated in a water bath at $40{ }^{\circ} \mathrm{C}$ was thoroughly mixed with an equal volume of phosphate buffered saline (PBS). Fifteen $1.5 \mathrm{ml}$ aliquots were pelleted by centrifugation $(16000 \mathrm{~g}$, $20 \mathrm{~m}$ ). Five of the samples were subjected to DNA extraction using the Instagene protocol as described by Djordjevic et al. (1998b) and five samples extracted using one chloroform:isoamyl alcohol extraction (CIAE). To perform this extraction individual samples were placed in an eppendorf tube that contained $200 \mu \mathrm{L}$ of $2 \%$ hexadecyltrimethylammonium bromide (CTAB), (1.4 M NaCl, $1 \%$ polyvinylpyrrolidone, $0.02 \mathrm{M}$ ethylenediaminetetraacetic acid, $0,1 \mathrm{M}$ Tris- $\mathrm{HCl}, \mathrm{pH}$ 8.0) and incubated for $5 \mathrm{~min}$ at $65^{\circ} \mathrm{C}$ in a dry block heater 
(Xtron, Australia). CTAB extracts were purified using chloroform:isoamyl alcohol (24:1, v/v) (Goodwin et al., 1994). The nucleic acids were precipitated with $25 \mu \mathrm{L}$ of sodium acetate $(3 \mathrm{M}, \mathrm{pH}$ $5.2)$ and $400 \mu \mathrm{L}$ of ice-cold ethanol (100\%). The suspension was incubated at $-20^{\circ} \mathrm{C}(20 \mathrm{~min})$ and then centrifuged $(16000 \mathrm{~g}, 20 \mathrm{~min})$. The resultant supernatant was discarded and the pellet was washed twice with ethanol $(70 \%)$, air dried and resuspended in $50 \mu \mathrm{L}$ of TE buffer $(10 \mathrm{mM}$ Tris$\mathrm{HCl}, \mathrm{pH}$ 8.0, $1 \mathrm{mM}$ EDTA). DNA samples were then stored at $-20{ }^{\circ} \mathrm{C}$ and $2 \mu \mathrm{L}$ was used in the PCR. The remaining 5 honey samples were subjected to a second CIAE.

For the bulk honey samples $25 \mathrm{ml}$ of honey was heated to $40^{\circ} \mathrm{C}$ in a water-bath then thoroughly mixed with an equal volume of PBS and centrifuged (27 $000 \mathrm{~g}, 20 \mathrm{~min}$ ). The supernatant was discarded and the pellet was resuspended in $2 \mathrm{ml}$ of SDW. $1.5 \mathrm{ml}$ of the solution was treated as described above and subjected to two CIAEs.

\subsubsection{Methods to extract DNA from adult bee tissue}

Individual adult bee tissues were placed in an eppendorf tube with a small quantity of sterile acid washed sand (Unilab, Australia). Each tissue was macerated with a sterile plastic micropestle in $200 \mu \mathrm{L}$ of $\mathrm{CTAB}$ and briefly vortexed $(5 \mathrm{~s})$ followed by a single CIAE except for the adult bee digestive tracts which received a second CIAE.

\subsubsection{Methods to extract DNA from larvae and pollen}

Whole larvae were prepared as for adult bee tissue except that no acid washed sand was added. Fifteen larval samples showing signs of EFB and collected from the same infected colony were used in comparative studies (see Sect. 2.3.1). Larval smears were prepared from 5 larvae and processed for PCR using Instagene (BioRad, USA) as described by Djordjevic et al. (1998a). Five whole larvae were prepared using a single CIAE and 5 were given a second extraction.

DNA was extracted from pollen samples using the same method for larval samples except that they were subjected to two CIAEs.

\subsection{Hemi-nested PCR for Melissococcus pluton}

The hemi-nested PCR was carried out according to the protocol of Djordjevic et al. (1998a) with the following modifications. In each reaction the enzyme used was 1 Unit Taq DNA polymerase (Roche Diagnostics, Germany) with $5 \mu \mathrm{L}$ of its accompanying $10 \times$ PCR buffer $(100 \mathrm{mM}$ Tris- $\mathrm{HCl}$,
$15 \mathrm{mM} \mathrm{MgCl} 2,500 \mathrm{mM} \mathrm{KCl})$. The $\mathrm{MgCl}_{2}$ concentration of the first generation PCR was reduced from $4 \mathrm{mM}$ to $3 \mathrm{mM}$ and the nested reaction concentration lowered to $1.5 \mathrm{mM} \mathrm{MgCl}_{2}$ to increase the sensitivity of the assay.

All PCR amplifications were performed in a PCRExpress thermal cycler (Hybaid, UK). Amplification products were electrophoresed $(80 \mathrm{~V}$, $1.5 \mathrm{~h})$ through $1-1.5 \%(\mathrm{wt} / \mathrm{vol})$ agarose gel containing ethidium bromide and visualized using UV light. Both positive (M. pluton crude DNA) and water controls (DNA-free reactions) were included in every PCR.

\subsection{Hemi-nested PCR specificity}

To test the specificity of the nested primers (MP1 \& MP3) PCR amplification was attempted with DNA from a range of bacterial species (Tab. I), including species closely related phylogenetically to $M$. pluton or commonly found in bee larvae (Cai and Collins, 1994; Djordjevic et al., 1998a). The concentration of purified DNA was determined spectrophotometrically (Eppendorf biophotometer, Germany). To examine the DNA preparation for the evidence of degradation, an aliquot was electrophoresed through $1.0 \%$ agarose $(55 \mathrm{~V}$, $1 \mathrm{~h})$.

Purified DNA (70 ng) from each isolate listed in Table II was used as template DNA in the heminested PCR. Water controls (DNA-free reactions) and positive controls (containing M. pluton DNA extracted from culture) were included in all reactions.

\subsection{Sensitivity of the hemi-nested PCR assay}

A 1 in 10 serial dilution series from $10 \mathrm{ng} / \mu \mathrm{L}$ to $10 \mathrm{ag} / \mu \mathrm{L}$ was prepared using purified $M$. pluton DNA diluted in TE buffer. From each of the ten tubes in the dilution series, $2 \mu \mathrm{L}$ was used as template for the first generation PCR (primers MP1 \& MP2). Using a $1 \mu \mathrm{L}$ aliquot from the first generation reaction, a hemi-nested PCR assay was performed using primers MP1 and MP3.

\section{RESULTS}

\subsection{Comparison of DNA extraction protocols for larvae and honey}

When Instagene was used for DNA extraction the first generation 486 bp $M$. pluton PCR product (primers MP1 \& MP2) 
Table I. DNA extraction protocols and bacterial species used to determine the specificity of primers (MP1 and MP3) used for the nested Melissococcus pluton PCR assay.

\begin{tabular}{ll}
\hline Bacteria & DNA extraction method \\
\hline Gram-positive bacteria & \\
Melissococcus pluton & Instagene matrix (BioRad, USA) \\
Paenebacillus larvae & Djordjevic et al. (1998a) \\
Paenibacillus alvei & Djordjevic et al. (1998a) \\
Spiroplasma melliferum & Djordjevic et al. (1998b) \\
Enterococcus faecium & Djordjevic et al. (1998a) \\
Enterococcus faecalis & Djordjevic et al. (1998a) \\
Enterococcus faecalis (NTCC 775) & Instagene matrix (BioRad, USA) \\
Enterococcus faecalis (ATCC 25619) & Instagene matrix (BioRad, USA) \\
Erysipelothrix rhusiopathiae & Djordjevic et al. (1998a) \\
Actinobacillus pleuropneumoniae & Instagene matrix (BioRad, USA) \\
Bacillus laterosporus (ATCC 64) & Instagene matrix (BioRad, USA) \\
Pseudomonas aeruginasa (NTC 10322) & Instagene matrix (BioRad, USA) \\
Gram-negative bacteria & \\
Pasteurella multocida & Djordjevic et al. (1998b) \\
Pasteurella multocida (1096) & Djordjevic et al. (1998b) \\
\hline
\end{tabular}

was not observed for the five honey or five larval samples from the infected colony. All 5 larval samples but none of the honey samples produced the second generation (MP1 and MP3) $276 \mathrm{bp} \mathrm{M}$. pluton PCR product.

When one CIAE was performed template for the first generation PCR was amplified in four of five diseased larvae and five honey samples. The fifth larva was positive in the second generation PCR.

Using two CIAEs five honey and five larval samples from the same infected colony produced the first generation product (data not shown).

\subsection{Epidemiological studies}

M. pluton template was amplified with the first generation PCR from 23/36 (63.9\%) of the samples from the infected colony (Tab. II). All 36 samples produced the secondgeneration product (Fig. 1).

From the healthy colonies from endemically infected areas 13/98 (13.3\%) of the samples yielded the first generation PCR product (larvae [2/24], broodnest honey and adult bee rectums [1/25])(Tab. II). The second-generation product was produced by $49 / 98(50.0 \%)$ of the samples (Tab. II). M. pluton was not detected in adult bee mouthparts and legs, or fresh cell washes and pollen. The digestive tracts (20) derived from Western Australian honey bees were also all negative (data not shown).

\subsection{Bulk honey samples}

The hemi-nested PCR assay detected $M$. pluton in 55/80 (68.8\%) of bulk honey samples whereas culture yielded M. pluton from 22/80 (27.5\%) of samples (Tab. III). Most culture positive samples yielded a sparse growth of $M$. pluton. Two samples yielded a profuse growth of $M$. pluton and these were the only two samples that were positive in the first generation PCR. All 4 Western Australian bulk honey samples were negative. However, in control experiments the first generation product was amplified from Western Australian honey that had been inoculated with M. pluton. 
Table II. Amplification of the M. pluton first and second generation PCR products from samples derived from honey bee colonies with or without EFB from endemic or EFB-free areas.

\begin{tabular}{|c|c|c|c|c|}
\hline $\begin{array}{l}\text { Number } \\
\text { of } \\
\text { colonies }\end{array}$ & $\begin{array}{c}\text { EFB disease } \\
\text { status of colony } \\
\text { (endemic/ EFB-free) }\end{array}$ & $\begin{array}{l}\text { Samples taken } \\
\text { and number }\end{array}$ & $\begin{array}{l}486 \text { bp } M . \text { pluton } \\
\text { product present }\end{array}$ & $\begin{array}{l}276 \text { bp } M . \text { pluton } \\
\text { product present }\end{array}$ \\
\hline \multirow[t]{8}{*}{1} & $\begin{array}{l}\text { Positive } \\
\text { (Endemic) }\end{array}$ & Fresh cell washes (5) & $2 / 5$ & $5 / 5$ \\
\hline & & $\begin{array}{l}\text { Adult bee } \\
\text { mouthparts (2) }\end{array}$ & $2 / 2$ & $2 / 2$ \\
\hline & & Adult bee legs (2) & $2 / 2$ & $2 / 2$ \\
\hline & & Adult bee rectums (2) & $2 / 2$ & $2 / 2$ \\
\hline & & Broodnest honey (5) & $5 / 5$ & $5 / 5$ \\
\hline & & Pollen (5) & $3 / 5$ & $5 / 5$ \\
\hline & & Larval guts only (5) & $2 / 5$ & $5 / 5$ \\
\hline & & Whole larvae (10) & $5 / 10$ & $10 / 10$ \\
\hline \multirow[t]{8}{*}{9} & $\begin{array}{l}\text { Negative } \\
\text { (Endemic) }\end{array}$ & $\begin{array}{l}\text { Adult bee digestive tracts } \\
\text { (12) }\end{array}$ & $0 / 12$ & $4 / 12$ \\
\hline & & Larvae (24) & $2 / 24$ & $16 / 24$ \\
\hline & & Broodnest honey (17) & $10 / 17$ & $16 / 17$ \\
\hline & & Adult bee mouthparts (5) & $0 / 5$ & $0 / 5$ \\
\hline & & Adult bee legs (5) & $0 / 5$ & $0 / 5$ \\
\hline & & Adult bee rectums (25) & $1 / 25$ & $13 / 25$ \\
\hline & & Fresh cell washes (5) & $0 / 5$ & $0 / 5$ \\
\hline & & Pollen (5) & $0 / 5$ & $0 / 5$ \\
\hline 1 & $\begin{array}{l}\text { Negative } \\
\text { (EFB-free) }\end{array}$ & $\begin{array}{l}\text { Adult bee digestive tracts } \\
\text { (20) }\end{array}$ & $0 / 20$ & $0 / 20$ \\
\hline
\end{tabular}

Table III. Honey culture and hemi-nested PCR results of bulk honey samples from various Australian states.

\begin{tabular}{lccc}
\hline $\begin{array}{c}\text { Source of sample } \\
\text { (by Australian State) }\end{array}$ & $\begin{array}{c}\text { Number } \\
\text { of samples }\end{array}$ & $\begin{array}{c}\text { No. and \% M. pluton } \\
\text { PCR positive samples } \\
\text { (276 bp fragment) }\end{array}$ & $\begin{array}{c}\text { No. and \% M. pluton } \\
\text { PCR positive samples } \\
\text { by culture }\end{array}$ \\
\hline Victoria & 27 & $24(89)$ & $11(40)$ \\
New South Wales & 24 & $16(67)$ & $9(39)$ \\
Queensland & 7 & $2(29)$ & 0 \\
South Australia & 11 & $11(100)$ & $2(17)$ \\
Tasmania & 7 & $2(29)$ & 0 \\
Western Australia & 4 & 0 & 0 \\
Total & $\mathbf{8 0}$ & $\mathbf{5 7}$ & $\mathbf{2 2}$ \\
\hline
\end{tabular}




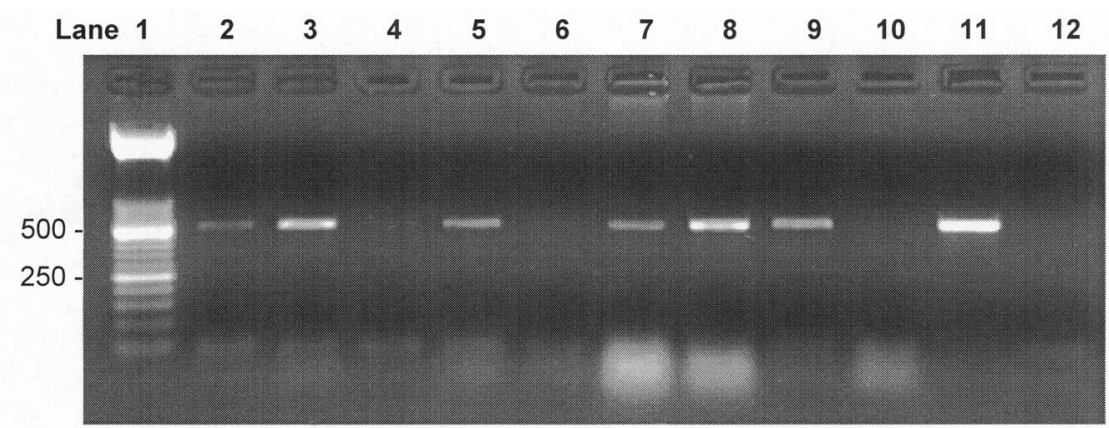

Figure 1. Agarose gel electrophoresis (1.5\%) ofproducts of the first generation 16SrRNA PCR using primers MP1 and MP2. The DNA fragment was amplified from DNA extractions of adult bee tissues in colonies with European foulbrood. Lane 1, 50 bp molecular markers. Lane 2, front legs. Lane 3, rear legs. Lane 4, wings. Lane 5, probiscis, Lane 6, mandibles. Lane 7, ventriculus. Lane 8, rectum. Lane 9, honey crop. Lane 10, WA bee digestive tract. Lane 11, $20 \mathrm{ng}$ M. pluton DNA (positive control). Lane 12, negative controls (genomic DNA-free).

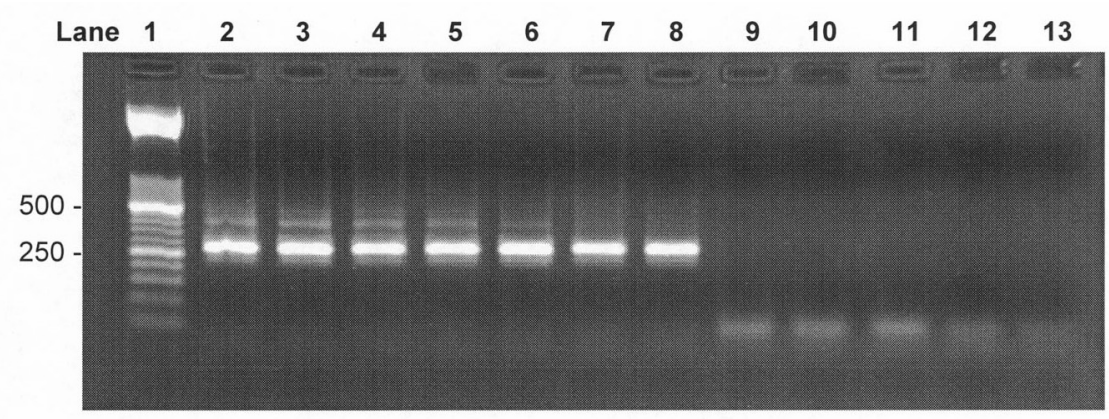

Figure 2. Agarose gel electrophoresis (1.5\%) of the second generation $276 \mathrm{bp}$ PCR product amplified using primers MP1 and MP3 from M. pluton crude DNA. The $276 \mathrm{bp}$ hemi-nested product was amplified in lanes 2-8, which contained $20 \mathrm{ng}, 2 \mathrm{ng}, 200 \mathrm{pg}, 20 \mathrm{pg}, 2 \mathrm{pg}, 200 \mathrm{fg}$ and $20 \mathrm{fg}$ respectively. The PCR did not amplify any product when $2 \mathrm{fg}, 200$ ag and 20 ag of DNA was added (lanes 9-11 respectively). Lanes 12 and 13 contained no DNA (water controls).

\subsection{Specificity and sensitivity of nested PCR primers}

Whole cell DNA extracted from the nontarget bacteria listed in Table I did not act as templates for the amplification of the $276 \mathrm{bp}$ nested product, confirming the specificity of the nested primers for the M. pluton $16 \mathrm{~S}$ rRNA gene. The $486 \mathrm{bp}$ product was successfully amplified in serial dilutions of $M$. pluton DNA down to $200 \mathrm{fg}$. Sensitivity was increased 10fold by the nested reaction, with the $276 \mathrm{bp}$ product observed in the $20 \mathrm{fg}$ dilution of template DNA (Fig. 2).

\section{DISCUSSION}

The laboratory diagnosis of EFB in diseased honey bee colonies is usually straight forward (Hornitzky and Smith, 1998). However, the detection of $M$. pluton in honey bee products or bees has proven to be difficult because of the fastidious growth requirements of $M$. pluton and the insensitivity of a range of techniques currently available for the detection of M. pluton (Hornitzky and Smith, 1998; Alippi, 1991; Pinnock and Featherstone, 1984). The sensitive detection of M. pluton in bee products is necessary for epidemiological 
studies and would also be useful to determine the status of bee products for export to areas such as New Zealand and Western Australia where EFB has not been reported.

The diseased larvae used for determining the efficacy of DNA extraction protocols were older and late in the infection cycle. These larvae can contain few $M$. pluton organisms due to the proliferation of secondary bacteria. This may have resulted in the failure of primers MP1 and MP2 to amplify adequate template for visualization from Instagene DNA extractions although the second generation product was detected. The use of a CIAE protocol for the recovery of DNA facilitated the detection of $M$. pluton in bee products and various bee tissues using PCR. However, a single CIAE produced a yellowish extract when used on bulk honey samples, pollen and adult bee digestive tracts. A second CIAE removed the discolouration and thus is likely to have decreased PCR inhibitors by further removing impurities in the sample prior to the precipitation of DNA (Koonjul et al., 1999). The second CIAE also facilitated the production of a better PCR product.

All individual adult bee tissues, pollen, cell washes and broodnest honey from the infected colony were shown to contain $M$. pluton, usually in the first generation PCR, which indicates that bees and bee products as well as diseased brood are a source of infection. This work has also demonstrated that these same sample types from healthy hives, except for fresh cell washes and pollen, can also contain M. pluton and that apparently healthy hives may be a source of EFB. Honey was also demonstrated to be commonly infected with $M$. pluton and hence, is a constant supply of bacteria to infect larvae where it reproduces and contaminates adult bees and comb cells, leading to further contamination of honey.

M. pluton was first reliably cultured from diseased larvae by Bailey (1957), with the culture technique later modified by adding nalidixic acid to the medium, which inhibits the growth of a common secondary bacterial invader Paenibacillus alvei (Hornitzky and Smith, 1998). In culture studies, Hornitzky and Smith (1998) demonstrated that 27 (6.2\%) of 434 bulk honey samples from eastern Australia contained M. pluton. However, the culture technique for M. pluton was shown to be insensitive with the recovery of $0.2 \%$ or less organisms. The hemi-nested PCR demonstrated that 55 of $80(68.8 \%)$ bulk honeys from eastern Australian States contained M. pluton, while only 22 of $80(27.5 \%)$ were culture positive, confirming the better sensitivity of the hemi-nested PCR.

Only two samples were positive in the first generation PCR, which illustrates that $M$. pluton is usually present in low concentration in bulk honeys. Interestingly, these two honey samples were the only ones to yield a profuse growth of M. pluton. Bulk honey samples from South Australia, Victoria and New South Wales had the highest prevalence of M. pluton infections with 11 of $11(100 \%), 24$ of 27 $(88.9 \%)$ and 16 of $24(66.7 \%)$ positive samples respectively. The negative results from the adult bee digestive tracts and bulk honey samples from Western Australia reinforces the EFB free status of this state.

The oligonucleotide primers of the first generation (MP1 \& MP2) have been shown to be specific for M. pluton (Djordjevic et al., 1998a). However, previous researchers were unable to compare $16 \mathrm{~S}$ rRNA gene sequences from many of the enterococci since they had not been sequenced at the time of that publication. M. pluton is most closely related phylogenetically to the genus Enterococcus (Cai and Collins, 1994). Recently, the 16S rRNA genes from 18 different Enterococcus species have been sequenced (Patel et al., 1998). Sequence comparisons of enterococcal $16 \mathrm{~S}$ rRNA gene sequences with primers MP1 and MP3 indicates that amplification of $16 \mathrm{~S}$ rRNA gene sequences from enterococcal species is unlikely. This is reinforced by the fact that both E. faecalis and E. faecium isolates used in this study did not produce the 276 bp PCR product when MP1 and MP3 were used (Tab. II).

The detection of M. pluton in larvae, adult bees tissues, pollen and honey in both healthy and diseased hives by PCR provides a specific and sensitive method for epidemiological studies of EFB such as monitoring the spread of latent EFB infections in newly infected areas. It also provides an alternative method to culture for the detection of $M$. pluton in bee products which has application in the certification of bees and bee products for export purposes. 


\section{ACKNOWLEDGMENTS}

We wish to thank the Rural Industries Research and Development Corporation for financial support and the Australian honey bee industry for supplying bulk honey samples. We also wish to thank Wendy Forbes, Helen Richardson and Dr Robert Faggian for their expert technical assistance.

Résumé - Détection de Melissococcus pluton chez l'Abeille domestique (Apis mellifera) et dans ses produits par PCR semi-nichée. La loque européenne est une maladie des larves de l'Abeille domestique (Apis mellifera L.) causée par la bactérie Melissococcus pluton. Elle est répandue dans la plupart des pays producteurs de miels; néanmoins elle n'a pas été signalée en Nouvelle Zélande ni dans l'ouest de l'Australie (Hornitzky and Wilson, 1989). En Australie il peut s'agir d'une grave maladie qui survient en général au printemps lorsque le nid à couvain s'agrandit (Graham, 1992). Le but de cette étude était de mettre au point la réaction en chaîne de la polymérase (PCR) seminichée (Djordjevic et al., 1998a) pour détecter $M$. pluton dans le miel, le pollen, les larves entières et les abeilles adultes et pour déterminer sa fréquence dans des échantillons de miel australien du commerce en gros.

On a prélevé 154 échantillons dans des colonies d'abeilles atteintes ou non de loque européenne et les avons analysés par PCR semi-nichée pour rechercher $M$. pluton en utilisant la méthode d'extraction de l'ADN par le mélange chloroforme:alcool d'isoamyle (CIAE). La PCR seminichée a permis de montrer la présence de $M$. pluton dans les 36 échantillons testés provenant d'une colonie malade et des infections sub-cliniques ont été détectées dans les tissus des abeilles adultes, dans les larves et le miel (49/98; 50,0 \%) prélevés dans les neuf colonies saines situées dans des zones où la loque européenne est endémique. Les 20 échantillons de tissus d'abeilles adultes provenant d'une colonie saine située en Australie occidentale où la loque européenne n'a jamais été signalée étaient négatifs. Un total de 80 échantillons de miels provenant de six états d'Australie a été analysé ; la PCR semi-nichée a montré que 55 des 80 échantillons $(68,8 \%)$ renfermaient $M$. pluton et que 22 des 80 échantillons $(27,5 \%)$ ont répondu positivement aux tests de culture (Hornitzky et Smith, 1998 ; Tab. II).

La détection par les tests PCR de M. pluton dans les tissus des abeilles adultes provenant de colonies infectées et de colonies apparemment saines illustrent le potentiel de contamination des cellules de couvain et du nectar par les abeilles adultes. La PCR semi-nichée a confirmé l'absence de $M$. pluton en Australie occidentale. Lors de tests contre 11 espèces de bactéries, y compris des bactéries phylogénétiquement apparentées ou celles que l'on trouve habituellement dans les colonies, la PCR semi-nichée n'a fourni aucun produit de PCR (Tab. I). Les études de sensibilité ont montré que la PCR seminichée détectait $20 \mathrm{fg}$ d'ADN génomique de M. pluton (Fig. 2).

La détection par PCR de $M$. pluton dans les larves, les abeilles adultes, le pollen et le miel fournit une méthode spécifique et sensible adaptée aux études épidémiologiques de la loque européenne pour déterminer l'extension des infections sub-cliniques dans les régions nouvellement infectées. Il procure aussi une méthode alternative de culture pour détecter $M$. pluton dans les produits de la ruche et un moyen de certifier pour l'exportation qu'abeilles et produits du rucher sont indemnes de M. pluton.

\section{Melissococcus pluton / loque américaine / détection / réaction en chaîne de la polymérase / Australie / PCR}

\section{Zusammenfassung - Der Nachweis von Melisso- coccus pluton in Honigbienen (Apis mellifera) und ihren Produkten mit Hemi-Nested PCR. Die Europäische Faulbrut (EFB), eine Krankheit der Larven der Honigbienen (Apis mellifera), wird durch das Bakterium Melissococcus pluton hervorgerufen. Es ist weltweit in den meisten honigerzeugenden Ländern verbreitet, aber bisher wurde es weder in Neuseeland noch in Westaustralien gefunden (Hornitzky and Wilson, 1989). In Australien kann es, häufig im Frühjahr bei anwachsendem Brutnest, $\mathrm{zu}$ einer ernsthaften Erkrankung führen (Graham, 1992). In dieser Untersuchung soll die Methode der Hemi-Nested PCR (Djordjevic et al., 1998a) zur Bestimmung von $M$. pluton in Honig, Pollen, intakten Larven und adulten Bienen weiteren- twickelt werden, um das Vorkommen von $M$. pluton in australischen Honigen im Großhandel zu bestimmen.}

Es wurden 154 Proben von infizierten und gesunden Völkern gezogen und mit der HemiNested PCR auf $M$. pluton überprüft, wobei die Extraktionsmethode CIAE DANN angewendet wurde. Bei allen 36 Bienenproben aus infizierten Völkern konnte $M$. pluton mit der Hemi-Nested PCR nachgewiesen werden. In den 9 gesunden Völkern, die im für $M$. pluton endemischen Gebiet standen, wurden unterschwellige Infektionen in den Geweben der adulten Bienen, in Larven und Honig (49/98; 50.0) gefunden. Alle 20 Gewebeproben von gesunden Völkern aus Westaustralien, wo noch kein EFB nachgewiesen wurde, waren negativ. Insgesamt wurden 80 Proben aus Honigcontainern aus 6 australischen Staaten analysiert. Bei 55 $(68,8 \%)$ konnte mit der Hemi-Nested PCR 
M. pluton nachgewiesen werden und von 22 $(27,5 \%)$ konnten Kulturen hergestellt werden (Hornitzky and Smith, 1998; Tab. II).

Der Nachweis von M. pluton im Gewebe von adulten Tieren von befallenen, aber scheinbar gesunden Völkern mit PCR zeigte das Potential einer Verseuchung von Brutzellen und Honig durch adulte Bienen. Die Hemi-Nested PCR bestätigte, dass $M$. pluton in Westaustralien nicht vorkommt. Beim Test gegen 11 Bakterienarten, einschließlich phylogenetisch verwandter Bakterien und Arten, die normalerweise im Volk vorkommen, ergab sich mit Hemi-Nested PCR kein PCR Produkt (Tab. I). In Empfindlichkeitstesten der Methode gelang es, $20 \mathrm{fg}$ der genomischen DNA nachzuweisen (Abb. 2). Diese PCR erwies sich als eine spezifische und empfindliche Methode zum Nachweis von M. pluton in Larven, adulten Biene, Pollen und Honig und ist somit für epidemiologische Untersuchungen von EFB geeignet, um das Ausmaß von subklinischen Infektionen in neu befallenen Gebieten zu bestimmen. Sie ist eine Alternative zur Bestimmung von $M$. pluton durch Kulturen und ein Mittel für die Zertifikation von $M$. pluton freien Bienen und ihren Produkten für den Export.

\section{PCR / Melissococcus pluton / Europäische} Faulbrut / Honigbienen / Australien

\section{REFERENCES}

Alippi A.M. (1991) A comparison of laboratory techniques for the detection of significant bacteria of the honey bee, Apis mellifera, in Argentina, J. Apic. Res. 30, 75-80.

Bailey L. (1957) The isolation and cultural characteristics of Streptococcus pluton and further observations on Bacterium eurydice, J. Gen. Microbiol. 31, 147-150.

Cai J., Collins M.D. (1994) Evidence for a close phylogenetic relationship between Melissococcus pluton, the causative agent of European foulbrood disease, and the genus Enterococcus, Int. J. Syst. Bacteriol. 44, 365-367.
Dade H.A. (1962) Anatomy and dissection of the honeybee, published by the Bee Research Association, London.

Djordjevic S.P., Noone K., Smith L., Hornitzky M.A.Z. (1998a) Development of a hemi-nested PCR assay for the specific detection of Melissococcus pluton, J. Apic. Res. 37, 165-174.

Djordjevic S.P., Eamens G.J., Ha H., Walker M.J., Chin J.C. (1998b) Demonstration that Australian Pasteurella multocida isolates from sporadic outbreaks of porcine pneumonia are non-toxigenic (tox $A$-) and display heterogeneous DNA restriction endonuclease profiles compared with toxigenic isolates from herds with progressive atrophic rhinitis, J. Med. Microbiol. 47, 679-688.

Goodwin P.H., Xue B.G., Kuske C.R., Sears M.K. (1994) Amplification of plasmid DNA to detect plant pathogenic mycoplasmalike organisms, Ann. Appl. Biol. 124, 27-36.

Govan V.A., Brozel V., Allsopp M.H., Davison S. (1998) A PCR method for the rapid identification of Melissococcus pluton, Appl. Environ. Microbiol. 64, 983-1985.

Graham J. (1992) The hive and the honey bee, Dadant and Sons, Hamilton, Ill.

Hornitzky M.A.Z., Smith L. (1998) Procedures for the culture of Melissococcus pluton from diseased brood and bulk honey samples, J. Apic. Res. 37, 293-294.

Hornitzky M.A.Z., Wilson S. (1989) A system for the diagnosis of the major bacterial brood diseases, $\mathrm{J}$. Apic. Res. 28, 191-195.

Koonjul P.K., Brandt W.F., Farrant J.M., Lindsay G.G. (1999) Inclusion of polyvinylpyrrolidone in the polymerase chain reaction reverses the inhibitory effects of polyphenolic contamination of RNA, Nucl. Acids Res. 27, 915-916.

Patel R., Piper K.E., Rouse M.S., Steckelberg J.R., Kohner P., Hopkins M.K., Cockerill F.R., Kline B.C. (1998) Determination of 16S rRNA sequences of Enterococci and application to species identification of nonmotile Enterococcus gallinarum isolates, J. Clin. Microbiol. 36, 33993407.

Pinnock D.E., Featherstone N.E. (1984) Detection and quantification of Melissococcus pluton infection in honeybee colonies by means of enzyme-linked immunosorbent assay, J. Apic. Res. 23, 168-170. 